NELLY BENCHEVA

DOI: $10.5604 / 00441600.1233097$

Agricultural University

Plovdiv

MILENA TEPAVICHAROVA

Higher School of Security and Economy

Plovdiv

AGNIESZKA WRZOCHALSKA

Institute of Agricultural and Food Economics -

National Research Institute

Warsaw

\title{
CHARACTERISTICS AND TRENDS IN THE DEVELOPMENT OF PROFESSIONAL COMPETENCE OF THE HUMAN CAPITAL IN THE AGRICULTURAL SECTOR
}

\begin{abstract}
During recent years, the development of professional competencies is more frequently linked with the processes of performance, evaluation and career development of the human capital. Their formation requires focused actions to improve particular knowledge, skills and abilities. The analysis of the status and trends in the professional competences of the human capital in the agricultural sector in Bulgaria reveals a number of opportunities for their effective use and management.

The purpose of this article is to outline the professional competences of the human capital in the agricultural sector by analysing and presenting the trends in their development.

The study covers the period between January and November 2015. It is based on data from polls specially designed for the purpose of the analysis, direct contacts, corporate documentation, etc. The interviews are applied to specify the data and information. The issues and prospects for the development of professional competences of the human capital in agriculture are presented and rated according to the responses received.
\end{abstract}

Keywords: professional competences, human capital, agricultural sector.

JEL Codes: A13, E24, J24. 


\section{Introduction}

Sophistication of technology, globalisation and the extension of the period of active employment, in recent decades, require continuous adaptation of the personal skills and professional competences of the human capital. This is associated with many changes and challenges in the professional development. At present, the issue of a lifelong career management, which requires a broad set of skills and knowledge, becomes increasingly more relevant. It guarantees that the individuals have the opportunity to successfully find a job and adapt to and develop their workplace, to cope with the professional tasks and to obtain satisfaction and adequate remuneration for their labour.

The accumulation of a set of competences supporting the application of the human resources in the agricultural sector requires purposeful activities to improve certain skills and abilities. They are the "lingua franca", by which employers and employees communicate, showing the quality of the social and personal orientation of the human capital on the farms of the agricultural sector. Along with the development of the changes occurring in the sector, the needs of the workforce grow and alter, too.

In recent years, the development of the professional competences in the agrarian sector is increasingly linked to the processes of performance evaluation and career development of the human capital. Their sophistication requires purposeful activity to improve certain knowledge, skills and abilities. The analysis of the status and trends in the development of professional competencies of the human capital in the agricultural sector in Bulgaria reveals a number of opportunities for their effective use and management.

The purpose of this article is to characterise the professional competencies of the human capital in the agricultural sector through analysis and presentation of the trends in their development.

\section{Materials and methods}

The study includes two target groups - employers and workers. The data from the first group allows for comparative characterisation and presentation of the trends in the professional competences of the human capital for both, the agricultural sector in general, and by sub-sectors - crop growing and animal breeding. The information on the second group makes it possible to compare the requirements of the employers with potential employees on the farms of the agricultural sector.

In order to characterise the professional competences we examined the opinions of owners, managers and professionals in Human Resource Management (HRM) from 156 holdings different in size, status and ownership in the agricultural sector. The majority of the surveyed farms are located in the South Central region (SCR), where, at the start of the study, the farms represented $27.76 \%$ of the total nationwide (MAF, 2015). 
Depending on the size, the surveyed farms are grouped into four groups, namely:

- From 1 to 10 employees $-46.79 \%$,

- From 11 to 50 employees $-35.89 \%$,

- From 51 to 100 employees $-10.11 \%$,

- More than 101 employees $-7.21 \%$.

Given the particularities of the production process in the plant production and livestock farms, the study is carried out separately for both sectors.

The differentiation of the holdings by sector is based on the classification of the farm types according to the Eurostat FSS 2007. It is assumed that the farm sector identity is determined by the majority of the output (more than $60 \%$ ).

When comparing the importance of knowledge and skills for career success, we analysed the opinions of representatives of the executive staff in the surveyed farms. For this purpose, we interviewed 296 workers and employers. The classification of the participants according to various criteria shows their wide scope (Figure 1).

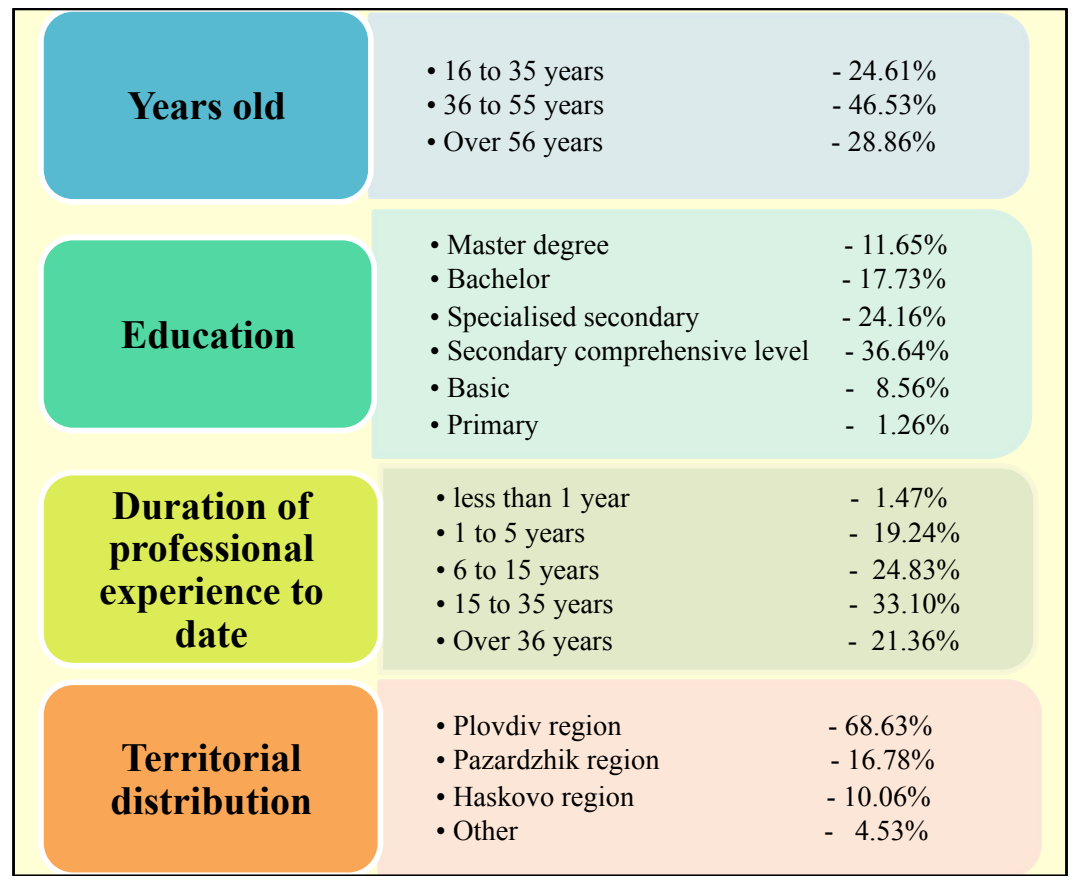

Fig. 1. Classification of the participants according to various criteria.

Sources: data from own research.

Two types of questionnaires were developed for the purposes of the study - separately for employers and employees. The survey focused on obtaining information on: 
- What are the most important competences for the employers when hiring new employees?

- What is the level of these skills for farm workers in the agricultural sector?

- Do the graduates with a degree in agricultural sciences have the necessary professional competences?

- When should I start the formation of professional competences?

We previously presented a list of 20 major groups of professional competencies and their concise definitions and description to the participants in the polls (Table 1). They were asked to rank them in a five-point scale, namely: 1 - not important, 2 - less important, 3 - important, 4 - very important, 5 - extremely important.

Table 1

Description of the main groups of professional competencies

\begin{tabular}{|c|c|c|}
\hline No. & Competence & Description \\
\hline 1 & Adaptability & $\begin{array}{l}\text { Ability to adapt to the corporate culture, flexibility, quick orientation to } \\
\text { the demands of the changing environment, including the ability } \\
\text { to work under pressure and tight deadlines }\end{array}$ \\
\hline 2 & $\begin{array}{l}\text { Readiness and willingness } \\
\text { to learn }\end{array}$ & $\begin{array}{l}\text { Receptivity, curiosity, desire for self-improvement, seeking } \\
\text { and receiving feedback }\end{array}$ \\
\hline 3 & Loyalty & Ethical attitude, honesty, integrity \\
\hline 4 & Efficiency & Ability to cope with work tasks with good results \\
\hline 5 & Computer skills & Using word processors, spreadsheets, Internet applications \\
\hline 6 & Leadership skills & $\begin{array}{l}\text { Skills in planning, managing and motivating people, skills } \\
\text { in decision-making, negotiation, etc. }\end{array}$ \\
\hline 7 & Mathematical skills & Working with numbers, accuracy, methodical skills, precision \\
\hline 8 & Ability to work in a team & $\begin{array}{l}\text { Cooperation, conflict resolution, good interpersonal relations, } \\
\text { sociability, ability to build relationships }\end{array}$ \\
\hline 9 & Motivation & Positive work attitude, enthusiasm \\
\hline 10 & Professional skills & $\begin{array}{l}\text { Specific skills and knowledge of the professional field, } \\
\text { an adequate idea of the work }\end{array}$ \\
\hline 11 & Communication skills & Clear, convincing and literate expression in oral and written form \\
\hline 12 & Critical attitude & Analytical skills, logic, impartiality, accuracy \\
\hline 13 & Office skills & $\begin{array}{l}\text { Finding and organizing information, documents, data; } \\
\text { work habits and use of office equipment }\end{array}$ \\
\hline 14 & Entrepreneurial skills & $\begin{array}{l}\text { Initiative, entrepreneurship, business knowledge and insight, } \\
\text { determination, ability to make decisions and take risks }\end{array}$ \\
\hline 15 & Self-presentation skills & $\begin{array}{l}\text { Skills for successful performance (including in a job application } \\
\text { and interview), confidence in one's own skills, positivity, } \\
\text { conviction, knowledge of business communication }\end{array}$ \\
\hline 16 & Creativity & Creativity, initiative, ingenuity, lateral thinking \\
\hline 17 & Technical skills & Specific skills to use specialised software programme and equipment \\
\hline 18 & Client attention skills & $\begin{array}{l}\text { Responsiveness, empathy, positive attitude, tact, tolerance, } \\
\text { patience, attentiveness }\end{array}$ \\
\hline 19 & Self-management skills & Responsibility, independence, organisation of time and work tasks \\
\hline 20 & Multilingual abilities & $\begin{array}{l}\text { Use (written and spoken) of a foreign language, } \\
\text { intercultural experience and knowledge }\end{array}$ \\
\hline
\end{tabular}

Sources: data from own research. 
The actual list has been prepared for the purposes of the study, in which the following were taken into account:

- Key competences formulated by the European Commission (The Definition..., 2010);

- Preliminary analysis of similar studies in Europe and around the world in recent years (Employers' perception..., 2010; Ready to grow..., 2010; Graduate Employability..., 2008)

- Overview of the most frequently mentioned skills and qualities that are required from applicants in job advertisements.

- Consultations with employers, educational experts and counselors who helped summarising the skills in 20 groups.

The study covers the period between January and November 2015. It is based on data from specially designed questionnaires for the purpose of the analyses, direct contacts, company documentation, etc. To specify the data and information, we used the method of the interview. Based on the responses received, the problems and prospects for the development of professional competencies of the human capital in the agricultural sector are presented and rated.

\section{Results and discussion}

\section{Characteristics of the professional competencies of the human capital in the holdings of the agricultural sector}

The building and improvement of professional competencies is emerging as a fundamental need because of:

- The difficulties for the realization which encounter the participants in the labour market during the years of transition;

- The growing gap between the traditional training programmes and the current goals and needs of professionals in the holdings of the agricultural sector;

- The underperformance of many institutional reforms, which in most cases do not affect the changes occurring in human resources.

The survey data on employers show that of all the proposed 20 professional competencies not even one has been assessed as "not important".

In the plant growing sector respondents identified as particularly important for the professional development of the staff the professional training, ability to work in a team, readiness and willingness to learn, adaptability, motivation, efficiency and self-management skills. They are rated as "very important" when hiring new employees with a grade of 4 and more (Table 2). 
Table 2 Evaluation of the employers of the importance of professional competencies when hiring new employees

\begin{tabular}{|c|c|c|c|}
\hline \multirow{2}{*}{ Professional competence } & \multicolumn{3}{|c|}{ Business sectors } \\
\hline & Agricultural sector & Plant growing & Livestock \\
\hline Professional skills & 4.69 & 4.67 & 4.71 \\
\hline Readiness and willingness to learn & 4.48 & 4.49 & 4.48 \\
\hline Ability to work in a team & 4.53 & 4.44 & 4.62 \\
\hline Adaptability & 4.37 & 4.34 & 4.40 \\
\hline Self-management skills & 4.27 & 4.18 & 4.36 \\
\hline Efficiency & 4.02 & 4.16 & 3.89 \\
\hline Motivation & 4.00 & 4.03 & 3.96 \\
\hline Communication skills & 4.10 & 3.96 & 4.24 \\
\hline Multilingual abilities & 3.87 & 3.66 & 4.08 \\
\hline Self-presentation skills & 3.38 & 3.56 & 3.21 \\
\hline Computer skills & 3.58 & 3.55 & 3.62 \\
\hline Client attention skills & 3.21 & 3.36 & 3.55 \\
\hline Loyalty & 3.15 & 3.23 & 3.06 \\
\hline Office skills & 3.35 & 3.18 & 3.51 \\
\hline Creativity & 3.09 & 3.03 & 3.15 \\
\hline Critical attitude & 2.83 & 2.72 & 2.94 \\
\hline Leadership skills & 2.75 & 2.71 & 2.78 \\
\hline Entrepreneurial skills & 2.65 & 2.70 & 2.61 \\
\hline Technical skills & 2.47 & 2.37 & 2.56 \\
\hline Mathematical skills & 2.38 & 2.23 & 2.53 \\
\hline Interviewed employers, \% & 100 & 68.5 & 31.5 \\
\hline
\end{tabular}

Sources: data from own research.

Similar views are expressed by employers in the livestock industry. They rank as very important the following professional competencies: professional training, readiness and willingness to learn, ability to work in a team, adaptability and self-management skills. Communication skills and language skills are also assessed as particularly significant.

From the presented data, it can be concluded that in the assessment of the professional competencies in both sub-sectors of the agricultural sector a number of similar results are observed. When hiring new employees, the majority of the employers identify as especially important the professional training, adaptability, ability to work in a team and readiness and willingness to learn. Some divergence 
of opinions was observed in terms of communication skills and language skills. According to the employers of the livestock industry, they are "very important", while for those in plant growing, they are rated only as "important".

As the least important for employment, the employers in the agricultural sector indicate the technical skills and mathematical skills.

\section{Assessment of the importance of professional competencies by the workforce in the farms of the agricultural sector}

The assessment of the professional competencies by the workers shows that to a large extent it is close to that of the employers (Table 3 ).

Table 3

Evaluation of employers and employees of the importance of professional competencies

\begin{tabular}{lcc}
\hline \multirow{2}{*}{\multicolumn{1}{c}{ Professional competence }} & \multicolumn{2}{c}{ Target groups } \\
\cline { 2 - 3 } & Employers & Executive staff \\
\hline Professional skills & 4.69 & 4.53 \\
Readiness and willingness to learn & 4.48 & 4.41 \\
Ability to work in a team & 4.53 & 4.40 \\
Adaptability & 4.37 & 4.23 \\
Self-management skills & 4.27 & 3.97 \\
Efficiency & 4.02 & 4.11 \\
Motivation & 4.00 & 4.01 \\
Communication skills & 4.10 & 3.24 \\
Multilingual abilities & 3.87 & 3.96 \\
Self-presentation skills & 3.38 & 3.46 \\
Computer skills & 3.58 & 3.23 \\
Client attention skills & 3.21 & 2.69 \\
Loyalty & 3.15 & 3.64 \\
Office skills & 3.35 & 3.55 \\
Creativity & 3.09 & 2.53 \\
Critical attitude & 2.83 & 2.36 \\
Leadership skills & 2.75 & 3.12 \\
Entrepreneurial skills & 2.65 & 3.10 \\
Technical skills & 2.47 & 2.17 \\
Mathematical skills & 2.38 & 2.14 \\
Respondents, number & $\mathbf{1 5 6}$ & $\mathbf{2 9 6}$ \\
\end{tabular}

Sources: data from own research. 
The respondents from both target groups assessed as particularly relevant the professional training, readiness and willingness to learn, ability to work in a team, adaptability, efficiency and motivation. The coincidence of positions leads us to conclude that the workers on the farms of the agricultural sector are aware of the major professional competencies for the employers. This can largely contribute to their successful career.

Some inconsistencies are observed in the assessment of entrepreneurial and leadership skills. Employees and workers consider them as important, as for the employers these competencies are not particularly important. In turn, they appreciate the high communication skills and ability to work with clients.

\section{Assessment of the acquired professional competencies of the degree graduates}

With reference to the evaluation of the acquired competencies of the degree graduates, the following conclusions can be drawn:

- Both employers and workers assess as comprehended in the highest degree the Readiness and Willingness to Work, Motivation, Communication Skills, Computer Skills and Creativity. (Figure 2 and 3).

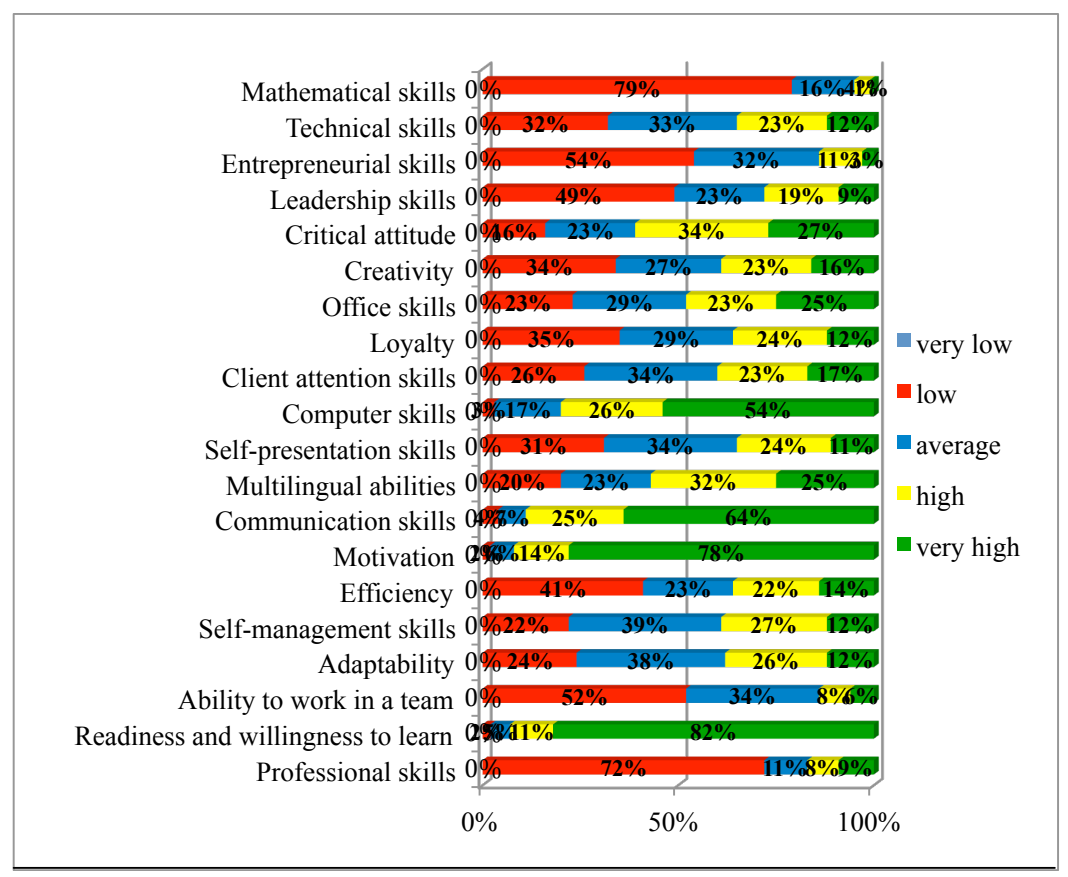

Fig. 2. Degree of acquired professional competencies of degree graduates in the field of the agricultural sciences in the opinion of the employers.

Sources: data from own research. 
- As professional competencies which are accumulated in the lowest degree, the employers and employees in the agriculture holdings place mathematical skills, entrepreneurial skills, professional training, efficiency, leadership skills, technical skills, critical thinking and office skills. The coincidence of positions shows that there is a clear picture of the opportunities and gaps in the educational system. One good alternative for the development and improvement of poorly-developed professional competencies is self-education. (Bencheva, Tepavicharova, 2011).

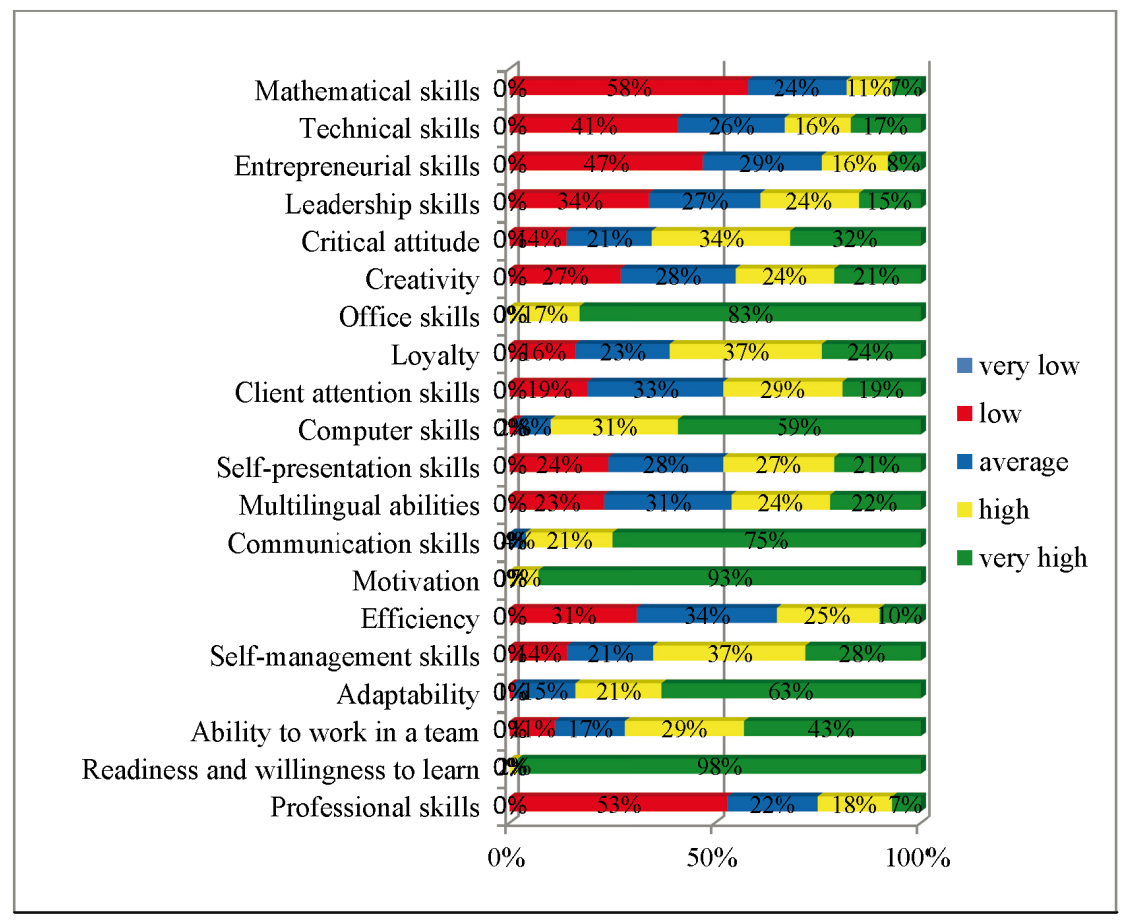

Fig. 3. Degree of acquired professional competencies of graduates of a university degree in the field of agricultural sciences in the opinion of the employees.

Sources: data from own research.

- Most employers assess as relatively good the language skills of the graduates of a certain degree in the field of agricultural sciences. This assessment is somewhat influenced by the fact that foreign language skills begin to develop at a very early age and continue throughout the period of study. The worker on the farms in the agricultural sector hold the opposite opinion. They define the language skills of graduates as unsatisfactory. Their opinion is prompted by the realization that in order to build language skills and competencies, it is required to actively use the language, which the educational systems at this stage cannot provide. 
- A certain discrepancy in the evaluation of employers and surveyed employees is observed in terms of adaptability skills, ability to work in a team, ability to work with clients and loyalty. According to the employers, these competencies are used to a much lower level than desired. However, the employees believe that the people with higher and secondary education in the field of agricultural sciences have a much higher degree of these competencies than demonstrated to the employers. This shows the need for targeted practical accumulation and improvement of the relevant skills and competencies.

\section{Period of building professional competencies}

As regards the period of building the professional competencies in both target groups, the highest percentage of respondents indicates high school (Table 4). It is assumed that this is a period of awareness and making a series of decisions on the social and personal orientation of the individual. This can facilitate the transition from education to professional development.

Table 4

Period of building professional competencies

\begin{tabular}{lcc}
\hline \multirow{2}{*}{ Period } & \multicolumn{2}{c}{ Target group } \\
\cline { 2 - 3 } & Employers (\%) & Eexecutive staff (\%) \\
\hline In early childhood & 21 & 3 \\
In elementary school & 20 & 7 \\
In basic school & 16 & 11 \\
In high school & 43 & 46 \\
Upon completion of the school & 0 & 9 \\
The university & 0 & 24 \\
Respondents, number & $\mathbf{1 5 6}$ & $\mathbf{2 9 6}$
\end{tabular}

Sources: data from own research.

For the employers, the accumulation of professional competencies in high school is the latest possible moment. Most of them (57\%), indicate previous periods, and $21 \%$ believe that the building of these skills should begin in early childhood. The employers consider the establishment of professional competencies as a long-term investment, while workers in the agricultural sector relate this process to the specific transitional period in life. According to them, the time for the development of professional knowledge and skills should start at a much later stage. 24\% of the respondents express the opinion that these competencies should be built after the completion of school and university. 


\section{Conclusion}

The building of a set of competencies supporting the adaptation of farm workers in the agricultural sector requires purposeful activity to improve certain skills and abilities. They are an essential element of the transition from the opportunity to "work" to the capacity "to develop professionally".

The professional skills are not separate skills needed for the transition from education to employment. They are a combination of knowledge and skills for career management, which need to be built from an early age. Their development and improvement has paramount importance for the successful careers of the workers in the farms in the agricultural sector.

Undoubtedly, an important part of this process is the development of appropriate mechanisms for bridging the gap between the education system and the requirements for successful professional development of the human potential in the holdings of the agricultural sector. Involving employers in the development of competency-oriented training programmes, career counselling and joint trainee service programmes are just some of the processes that can be initiated. 


\section{Literature:}

Bencheva, N., Tepavicharova, M. (2011). Autodidactic instruments for increasing the expertise of managers and staff. National Conference "Learning from the crisis - lessons learned, recommendations and strategies", CEA, 13 May 2011, Plovdiv, pp. 155-167.

CIPD, Competency and Competency Framework Survey. Latest version April 2007.

Dubois, D., Rothwell, W. (2004). Competency-Based Human Resource Management. Davies - Black Publishing.

Employers' perception of graduate employability (2010). Flash Euro barometer. Retrieved from: http://ec.europa.eu/public_opinion/flash/fl_304_en.pdf.

Graduate Employability: What do employers think and want? (2008). Retrieved from: http:// ec.europa.eu/education/higher-education/doc/business/graduate_en.pdf.

Lisbon Council - "Europe 2020: Why Skills are Key for Europe's Future”. Retrieved from: http://www.lisboncouncil,net/publication/publication/54-skillseuroprsfuture.html.

MAF (2015). Agrostatistics, Structure of the Agricultural Holdings.

Project "Development and implementation of an information system to evaluate the competence of the workforce in sectors and regions". Concept for the establishment of a national reference network.

Ready to grow: business priorities for education and skills. Education and skills survey, (2010). Retrieved from: http://www.cbi.org.uk/ndbs/content.nsf/802737AED3E3420580256706 005390AE/C4393B860D00478E802576C6003B0679.

Study of professional competencies of human capital in the agricultural sector. January-November 2015.

The Definition and Selection of Key Competencies (2010). Retrieved from: http://www. oecd.org/dataoecd/47/61/35070367.pdf. 
NELLY BENCHEVA

Uniwersytet Rolniczy

Płowdiw, Bułgaria

MILENA TEPAVICHAROVA

Wyższa Szkoła Bezpieczeństwa i Gospodarki

Płowdiw, Bułgaria

AGNIESZKA WRZOCHALSKA

Instytut Ekonomiki Rolnictwa i Gospodarki Żywnościowej

- Państwowy Instytut Badawczy

Warszawa, Polska

\title{
CHARAKTERYSTYKA I KIERUNKI ROZWOJU KOMPETENCJI ZAWODOWYCH KAPITAŁU LUDZKIEGO W SEKTORZE ROLNYM
}

\begin{abstract}
Abstrakt
W ostatnich latach rozwój kompetencji zawodowych jest coraz częściej zwiazany z wynikami i ocena kapitatu ludzkiego oraz rozwojem kariery. Tworzenie kapitału ludzkiego wymaga działan skoncentrowanych na poprawie konkretnej wiedzy, konkretnych umiejętności i zdolności. Analiza stanu i kierunków rozwoju kompetencji zawodowych kapitatu ludzkiego w sektorze rolnym Bułgarii ukazuje wiele możliwości jego skutecznego wykorzystania i zarzadzania.

Niniejszy artykut ma na celu zidentyfikowanie kompetencji zawodowych kapitału ludzkiego w sektorze rolnym przez analizę i prezentację kierunków jego rozwoju.

Praca obejmuje okres od stycznia do listopada 2015 r. Opiera się na danych zaczerpniętych $z$ ankiet specjalnie zaprojektowanych do tego celu oraz na bezpośrednich kontaktach, dokumentacji firmowej itd. Do sprecyzowania danych $i$ informacji zastosowano metode wywiadu. Problemy i możliwości rozwoju kompetencji zawodowych kapitału ludzkiego w rolnictwie zaprezentowano i oceniono według otrzymanych odpowiedzi.
\end{abstract}

Slowa kluczowe: kompetencje zawodowe, kapitał ludzki, sektor rolny.

Zaakceptowano do druku - Accepted for print: 10.04.2017.

0 ile nie jest to stwierdzone inaczej, wszystkie materiały na stronie są dostępne na licencji Creative Commons Uznanie Autorstwa 3.0 Polska. Pewne prawa zastrzeżone na rzecz Instytutu Ekonomiki Rolnictwa i Gospodarki Żywnościowej - PIB.

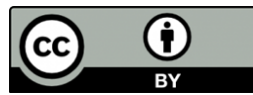

